\title{
Journal Policies on Conflict of Interest: If this Is the Therapy, What's the Disease?
}

\author{
Sheldon Krimsky \\ Department of Urban and Environmental Policy, Tufts University, Medford, Mass., USA
}

The editorial by Giovanni Fava in a recent issue of this journal [1] brings to our attention the multifarious effects of corporate, for-profit interests on scientific research and clinical medicine. Some of these influences are, to use a medical metaphor, at the subclinical level. We suspect, but cannot detect, the salient effects on research and the enterprise of science resulting from the growing influence of industry on academic scientists and researchers at nonprofit institutes. In the United States it has been the goal of several federal policies through laws, economic tax incentives, legal decisions and executive orders to create closer linkages between universities and for-profit companies [2]. Other countries are following, albeit more slowly, the academic-industry model currently in fashion in the United States [3, 4].

Three areas of possible impact are the selection of research questions, biasing of research outcomes, and public perception of science. It is difficult to study private funding influences on the choice of research questions. In some fields, such as weed science, where private funding is extensive, the influences may be fairly obvious. For one prominent journal, we documented a significant bias toward studies involving high input chemical weed control, over alternative methods, including integrated pest management deploying nonchemical methods [5]. In the field of weed science the choice of research questions is heavily influenced by the interests of chemical-industry benefactors. In certain fields of biomedical sciences where research and journals are strongly influenced by private interests, it is reasonable to expect similar effects on the skewing of research strategies. As Fava notes, certain data do not get published because the gatekeepers of 'worthy knowledge' have a financial interest in marginalizing research agendas that threaten corporate profits.

Potential relationships between funding source and bias are also fairly complicated to study. The few studies that have been published suggest that researchers studying a drug and funded by manufacturers are more likely to reach a favorable interpretation of its safety, efficacy, or cost-effectiveness than those studying the same drug but funded by not-for-profit institutions [6-10]. The reason we haven't found more evidence of bias associated with financial conflicts of interest is that we haven't looked. The cases that do come to light usually are revealed in the aftermath of a drug withdrawal $[11,12]$.

A third potential outcome of conflicts-of-interest among independent scientists is the impact they may have on the public's trust in science. While the erosion of trust in science has been cited as an outcome of academic entrepreneurship, no credible studies have documented the effect. Nevertheless, some journal editors are sufficiently moved by the prospect that their journal will lose

\begin{tabular}{ll}
\hline KARGER & ( ) 2001 S. Karger AG, Basel \\
Fax +4161306 1234 34 -3190/01/0703-0115\$17.50/0 \\
$\begin{array}{l}\text { E-Mail karger@karger.ch } \\
\text { www.karger.com }\end{array}$ & $\begin{array}{l}\text { Accessible online at: } \\
\text { www.karger.com/journals/pps }\end{array}$
\end{tabular}

Professor Sheldon Krimsky

Department of Urban \& Environmental Policy, Tufts University

97 Talbot Ave, Medford, MA 02155 (USA)

Tel. +1 617627 3394, Fax +1 6176273377

E-Mail sheldon.krimsky@tufts.edu 
credibility that they have sought remedy through disclosure policies.

Fava supports disclosure as 'a first and essential step for dealing with conflict of interest contamination in science' but questions how many journals share this policy. One study that looked at 25 basic science and 25 clinical journals with the highest-immediacy index ratings from Institute of Scientific Information (ISI) found that 20 of 47 journals (43\%) reported they had policies on conflicts of interest [13]. My colleague L.S. Rothenberg of the UCLA Medical School and I have recently completed a systematic investigation of journal policies on conflict of interest. Some of the results were reported at a scientific meeting $[14,15]$. We examined 1,400 journals selected from the Science Citation Index of ISI by their ratings of two impact indicators ('impact factor' and 'times cited factor'). For the year 1997, 15.7\% of these 'high impact' journals had conflict-of-interest disclosure policies for authors. We analyzed a subset of 181 peer-reviewed journals, 29 foreign $(n=29)$, out of the 220 journals with disclosure policies. We, along with a small group of students, visually inspected over 60,000 original research items and found author disclosures of personal financial interests in $0.5 \%$ of the articles. Moreover, $66 \%$ of the journals we inspected had zero disclosures of author personal financial interest for 1997. Based upon evidence of intense commercialization within the biomedical sciences, it was curious to us that there were so few disclosures. Were the authors reporting honestly? Were the editors publishing disclosures they received? Were the policies unambiguous? Further studies in progress will answer some of these questions.

During our investigation we identified a group of 6 journals that required authors to select one of several statements within a standardized format that described any potential financial benefits either they or their institution has received or may receive from their research. We call these the 'template journals' since they require each author to select an option from the menu of choices and report the selection for each article published. In principle, these journals have a disclosure rate of $100 \%$. Except for a few outliers, this was borne out by our data. But these journals reveal no details about authors' financial ties and therefore do not provide any useful information to the reviewers, readers, or editors about how those ties might bias their results. Other journals leave a lot of discretion to the author to report 'information about the authors' professional and financial affiliations that may be perceived to have biased the presentation' [16].
I believe that readers, reviewers, and editors should have information on the funding sources and personal financial interests of authors related to the subject matter of the publication. When scientists disagree on the interpretation of data, the social context of the scientist can be a vital clue to explaining differences in scientific judgment and tacit assumptions used in studies. Too often we learn how these contextual issues play a role in the aftermath of decisions and publications. The journal Nature is one of the last world class publications that is doggedly opposed to requiring authors to disclose financial interests. Its editors are not convinced that financial interests will affect the outcome of a scientific study or review [17]. How many of us would consider a disclosure of funding source, consultancies, and equity interests irrelevant to a paper on 'safe cigarettes'? There are so many aspects of science that remain outside the ken of peer reviewers. Conflict-of-interest information can sharpen, not discredit, the process of peer review.

Author disclosure of competing interests is, as Fava noted, a necessary but not sufficient response to the problem of scientific integrity. It doesn't address the underlying problem that academic science has become colonized by private interests and that too many scientists have become stakeholders. It is up to the academic institutions and government agencies to set restrictions against the most egregious conflicts of interest.

Societies that respect the inviolability of academic integrity must recalibrate the balance in the incentive system between the rights of academic scientists to pursue personal and institutional financial gains and the public's interest in incorruptible science. 


\section{References}

1 Fava GA: Conflict of interest and special interest groups. Psychother Psychosom 2001;70:15.

2 Krimsky S: University entrepreneurship and public purpose; in DeForest P, Frankel MS, Poindexter JS, Weil V (eds): Biotechnology: Professional Issues and Social Concerns. Washington, American Association for the Advancement of Science, 1988, pp 34-42.

3 Normile D: Japan hopes to cash in on industryuniversity ties. Science 1996;274:1457-1458.

4 Monbiot G: Science is selling out to business. Guardian, July 6, 2000.

5 Krimsky S, Wrubel R: Agricultural Biotechnology and the Environment. Urbana, University of Illinois Press, 1996, p 53.

6 Davidson RA: Source of funding and outcome of clinical trials. J Gen Intern Med 1986;3: 155-158.
7 Friedberg M, Saffran B, Stinson TJ, Nelson W, Bennett CL: Evaluation of conflict of interest in economic analysis of new drugs used in oncology. JAMA 1999;282:1453-1457.

8 Krimsky S: Conflict of interest and cost-effectiveness analysis. JAMA 1999;282:14741475.

9 Stelfox HT, Chua G, O'Rourke K, Detsky AS: Conflict of interest and the debate over calcium-channel antagonists. N Engl J Med 1998; 338:101-106.

10 Wazana A: Physicians and the pharmaceutical industry. Is a gift ever just a gift? JAMA 2000; 283:373-380.

11 Gerth J, Stolberg G: Another part of the battle: Keeping a drug on the shelves of stores. New York Times, December 13, 2000, A17.

12 Willman D: NIH director calls for review of scientist's ties to firm. Los Angeles Times, December 16, 1998, A28.
13 McCrary SV, Anderson CB, Jakovljevic J, Kahn T, McCullough LB, Wray NP, Brody BA: A national survey of policies on disclosure of conflicts of interest in biomedical research. NEJM 2000;343:1621-1626.

14 Krimsky S: Will disclosure of financial interests brighten the image of entrepreneurial science. Talk delivered at the 1999 AAAS Annual Meeting, Anaheim, Jan 1999.

15 King R Jr: Medical journals rarely disclose researchers ties. Wall Street Journal, February 2, 1999, B1;B4.

16 Instructions to authors. Science <http:/ /www.sciencemag.org/misc/con-info.shtml.> Accessed February 17, 1998.

17 Editorial: Avoid financial correctness. Nature 1997;385:469. 